\title{
Generation and analysis of expressed sequence tags (ESTs) from cambium tissue CDNA libraries of contrasting genotypes of Eucalyptus globulus Labill
}

\author{
Juan Pedro Elissetche*, Alexis Salas-Burgos, Renan Garcia, Carola Iturra, Regis Teixeira, Jaime Rodriguez, \\ Sofia Valenzuela
}

From IUFRO Tree Biotechnology Conference 2011: From Genomes to Integration and Delivery Arraial d'Ajuda, Bahia, Brazil. 26 June - 2 July 2011

In the present study, reported the generation and analysis of ESTs of cDNA libraries from cambium tissue of secondary xylem obtained of two genotypes of Eucalyptus globulus contrasting in wood density and pulp yield. The sequences were blasted and annotated to compare with genome and ESTs database of other plant species. The goal of study was to determinate wich genes was differentially expressed and compare levels of transcript, validated by $\mathrm{qRT}$-PCR, in each genotype involved in wood formation, to explain the differences founding in wood traits of contrasting genotypes.Sequences obtained was 450,000 ESTs of which approximately 21,000 sequences showed homology with genes of different vascular plants, mainly Vitis vinifera, Populus sp, Eucalyptus $s p$, Ricinus $s p$. Moreover, it was determined that 265 genes differentially expressed in both genotypes, and 41 genes were directly involved in wood formation process (xylogenesis). Of the 41 differentially expressed genes could be determined that mainly correspond genes involved in lignin biosynthesis pathway which $\mathrm{HCT}, \mathrm{C} 3 \mathrm{H}, \mathrm{CAD}, \mathrm{PAL}, \mathrm{COMT}$ and $\mathrm{F} 5 \mathrm{H}$ and lignin polymerization like laccase and peroxidase. Otherwise we found genes involved in carbohydrate biosynthesis (cellulose and hemicellulose) among which Sussy, UDP glucose dehydrogenase, UDP-mannose dehydrogenase and $\beta$-xylosidase. Also we described genes involved in morphological characteristics of fiber such FLA, XTH and transcription factors such MYB and LIM related to

\footnotetext{
* Correspondence: jelisset@udec.cl

Genomica Forestal SA, Barrio Universitario s/n, Centro de Biotecnología,
} Universidad de Concepción, Concepción, 403000, Chile fiber length, microfibrillar angle and extensibility of cell wall. Finally some of these genes were validated by the qRT-PCR technique to determine the level of transcripts in each genotype.

Published: 13 September 2011

doi:10.1186/1753-6561-5-S7-P108

Cite this article as: Elissetche et al:: Generation and analysis of expressed sequence tags (ESTs) from cambium tissue cDNA libraries of contrasting genotypes of Eucalyptus globulus Labill. BMC Proceedings 2011 5(Suppl 7):P108.
Submit your next manuscript to BioMed Central and take full advantage of:

- Convenient online submission

- Thorough peer review

- No space constraints or color figure charges

- Immediate publication on acceptance

- Inclusion in PubMed, CAS, Scopus and Google Scholar

- Research which is freely available for redistribution

Submit your manuscript at www.biomedcentral.com/submit
C Biomed Central

\section{CiolMed Central}

